\title{
A non-synonymous lactotransferrin gene polymorphism and dental caries in 12-year-old children from the West Pomeranian region in Poland
}

\section{Niesynonimiczny polimorfizm genu laktotransferyny i próchnica zębów u 12-letnich dzieci z Pomorza Zachodniego}

\author{
Rafał Rojek', Klaudyna Lewandowska², Agnieszka Boroń2, Agnieszka Małyszek², Paweł Jakubiszyn², \\ Jeremy Simon Clark ${ }^{2}$, Thierry van de Wetering ${ }^{2}$, Mariusz Kaczmarczyk², Andrzej Ciechanowicz ${ }^{2}$ \\ ${ }^{1}$ Pomorski Uniwersytet Medyczny w Szczecinie, Zakład Stomatologii Dziecięcej, al. Powstańców Wlkp. 72, 70-111 Szczecin \\ Pomeranian Medical University in Szczecin, Department of Paediatric Dentistry \\ ${ }^{2}$ Pomorski Uniwersytet Medyczny w Szczecinie, Zakład Biochemii Klinicznej i Molekularnej, al. Powstańców Wlkp. 72, 70-111 Szczecin \\ Pomeranian Medical University in Szczecin, Department of Clinical and Molecular Biochemistry \\ $\triangle$ aciech@pum.edu.pl
}

\begin{abstract}
Introduction: Dental caries is an infectious disease affecting $60-90 \%$ of children around the world and therefore is the most common chronic disease in childhood. Lactotransferrin, encoded by $L T F$ gene, is a salivary protein that limits microbial growth. The c.140A $>$ G transition in the $L T F$ gene (rs1126478), which results in a change from lysine $(\mathrm{K})$ to arginine $(\mathrm{R})$ at amino acid position 47 of lactotransferrin protein (p.K47R), significantly decreases bactericidal activity against Streptococcus mutans. Therefore, this raises the question of whether LTF: c.140A $>$ G polymorphism is associated with risk of caries in Polish children with permanent dentition.

Materials and methods: The rs1126478 LTF polymorphism was identified by sequencing genomic DNA isolated from buccal epithelial cells of 210 12-year-old children of European-descent from
\end{abstract}

West Pomerania in Poland (59 rural children and 151 urban children). In the studied subjects, the decay-missing-filled teeth (DMFT) index ranged 0-14, and children with a DMFT value of 0 were treated as caries-free subjects (control group).

Results: The caries frequency and mean DMFT in rural children were significantly higher than in urban children. Multiple logistic regression analysis, with adjustment for gender and place of permanent residence, revealed no significant association between LTF polymorphism and risk of caries.

Conclusions: Our study shows that residence in rural areas, but not $L T F$ c.140A $>$ G polymorphism, is a risk factor for caries in 12-year-old children from West Pomerania.

Keywords: dental caries; permanent dentition; children; genetic polymorphism; lactotransferrin.

\begin{abstract}
ABSTRAKT
Wstęp: Próchnica zębów jest chorobą zakaźną dotykającą 60-90\% dzieci na całym świecie, stąd też jest ona uważana za najczęstszą chorobę przewlekłą okresu dzieciństwa. Laktotransferyna, kodowana przez gen $L T F$, jest obecnym w ślinie białkiem, które ogranicza rozwój drobnoustrojów. Tranzycja c.140A>G w genie LTF (rs1126478), której skutkiem jest substytucja lizyny $(\mathrm{K})$ przez argininę $(\mathrm{R}) \mathrm{w}$ pozycji 47 łańcucha polipeptydowego laktotransferyny (p.K47R), znacznie zmniejsza aktywność bakteriobójczą tego białka, skierowaną przeciw Streptococcus mutans. Stąd też pytanie, czy polimorfizm LTF: c.140A $>\mathrm{G}$ wiąże się z ryzykiem próchnicy u polskich dzieci z uzębieniem stałym.

Materiały i metody: Identyfikację polimorfizmu rs1126478 LTF przeprowadzono metodą sekwencjonowania w próbkach genomowego DNA, wyizolowanego z komórek nabłonka jamy
\end{abstract}

\section{INTRODUCTION}

Caries is a complex disease linked to lifestyle and environmental factors, educational and socio-economic status, and genetic susceptibility. Untreated caries in permanent teeth was the most prevalent condition worldwide in 2010, affecting 2.4 billion people [1]. The population of 12-year-old children with ustnej 210 dzieci 12-letnich (59 dzieci ze wsi i 151 dzieci z miasta) pochodzenia europejskiego z regionu Pomorza Zachodniego. U badanych osób wartość wskaźnika intensywności próchnicy (PUW) wynosiła 0-14, a dzieci ze wskaźnikiem PUW równym o traktowano jako osoby bez próchnicy (grupa kontrolna). Wyniki: Częstość próchnicy i średnia wartość PUW u dzieci mieszkających na wsi były istotnie większe w porównaniu do tych wskaźników u dzieci z miasta. Analiza w modelu regresji logistycznej z uwzględnieniem korekty względem płci i miejsca stałego zamieszkania wykazała brak istotnego związku między polimorfizmem $L T F$ a ryzykiem próchnicy.

Wnioski: Wyniki badania wskazują, że stałe zamieszkanie na wsi, a nie polimorfizm $L T F$ c.140A $>\mathrm{G}$, jest czynnikiem ryzyka próchnicy u 12-letnich dzieci z Pomorza Zachodniego.

Słowa kluczowe: próchnica zębów; uzębienie stałe; dzieci; polimorfizm genetyczny; laktotransferyna.

complete permanent dentition of different degree of enamel maturity represents the most appropriate age range for the assessment of both caries prevalence and its prevention efficacy [2]. The estimated caries burden of disease in Europe in 2015, for the indicator age of 12-year-olds expressed using the specific weighted decay-missing-filled teeth (DMFT) index was 1.81, but in Poland reached 2.8 [3]. It is noteworthy that 
the mean DMFT index in 12-year-old Poles was smaller than 3.0 for the first time in the 30 -year-history of national epidemiologic studies of caries [3, 4]. In 2011 the mean DMFT index in 12-year-old Polish children was 3.5 with a difference between rural children and urban children (3.8 and 3.4, respectively) [4]. Differences in the dental status in 12-year-olds between children from rural areas and urban children was shown by Rodakowska et al. in the Podlaskie region [5] and previous study of Rojek et al. carried out in the West Pomeranian Province of Poland [6]. Mean DMFT index and caries prevalence (DMFT $\geq 1$ ) in 12-year-olds from West Pomeranian region were 3.5 and $86.2 \%$, respectively. In addition, both mean DMFT index and caries prevalence in rural children were significantly higher as compared to urban children (4.3 vs. 3.0, and $93.4 \%$ vs. $81.8 \%$, respectively) [6]. Rodakowska et al. emphasized that such differences were largely caused by the lower socio-economic status of rural children, including both unsatisfactory dental hygienic habits and worse access to dental services [5].

The first defense mechanism of the human body against caries is saliva. A constant flow rate of saliva removes bacteria from the oral cavity, while the content of the saliva reduces pathogen growth. Some salivary proteins have an antibacterial effect, such as immunoglobulins, mucins, agglutinins, lysozyme, lactoperoxidase and lactotransferrin $[7,8,9]$.

Lactotransferrin (LTF), also known as Lactoferrin, is a nonenzymatic antibacterial metalloprotein with a molecular mass of about $80 \mathrm{kDa}[10,11]$. Lactoferrin can be found in several mammalian fluids, such as milk, tears, semen, sweat and saliva, and has antifungal, antibacterial, antiviral and antiparasitic activity $[11,12]$. Lactotransferrin (with 710 amino acids) is encoded by the $L T F$ gene localized on human chromosome 3 p21.3, and this gene spans approximately $24.5 \mathrm{~kb}$ of genomic DNA with 17 exons [13]. The LTF: c.140A $>$ G transition (rs1126478) causes a substitution of lysine (K) by arginine (R) at amino acid position 47 of the LTF protein (p.Lys47Arg or p.K47R), which in vitro significantly decreases bactericidal activity against cariogenic Streptococcus mutans [14]. Results of a pilot genetic study revealed that "wild-type" LTF homozygotes (AA homozygotes) were less likely to have caries in permanent dentition [15]. However, other studies concerning the association between the $L T F$ rs1126478 polymorphism and the risk of caries demonstrated conflicting results $[8,16,17]$.

The aim of our study was to investigate the association between the LTF rs1126478 polymorphism and the predisposition to dental caries in 12-year-old rural and urban children from West Pomerania.

\section{MATERIALS AND METHODS}

The study was conducted in accordance with the Declaration of Helsinki and was approved by the Bioethics Committee of the Pomeranian Medical University in Szczecin. Parents of child subjects were informed about study objectives and gave their signed informed consent for inclusion before their children participated in the study. The study group consisted of
210 12-year-old children of European descent (107 girls and 103 boys), among them: 59 children lived in the rural area near the town of Łobez and 159 children were urban residents either from this town (ca. 10000 inhabitants) or from Szczecin (ca. 400000 inhabitants). Caries was defined according to WHO caries diagnostic criteria as the value of DMFT $\geq 1$. Children with DMFT value equal o were treated as the caries-free subjects (control group) [18].

Genomic DNA was extracted from buccal epithelial cells using a commercially available DNA isolation kit (PrepFiler ${ }^{\circledR}$ Express Forensic DNA Extraction Kit, Applied Biosystems, Life Technologies Polska, Warsaw, Poland). Amplification of the 265-bp LTF sequence including the c.140A $>$ G transition was performed by PCR using: 5'CTGGCTGG CCGTAGGAGGAGTG-3` as the forward primer and 5-GCCCAACAGGTGAAGCAGAG GAAG-3 as the reverse primer. Subsequently, PCR amplification products were purified using Exonuclease I and FastAP Thermosensitive Alkaline Phosphatase (ThermoFisher Scientific Inc., Waltham, MA USA) according to manufacturer procedures. Sequencing of the products used BigDye ${ }^{\circledR}$ Terminator v3.1 Cycle Sequencing Kits (Applied Biosystems, Life Technologies Polska, Warsaw, Poland). Electrophoresis and analysis were performed according to manufacturer procedures using an ABI PRISM 3100-Avant machine (Data Collection Software v2.0, Sequencing Analysis Software v5.1; Applied Biosystems).

Possible divergence of LTF genotype frequencies from HardyWeinberg equilibrium and the differences in frequency distribution of caries, $L T F$ genotypes and $L T F$ alleles between groups were assessed using a $\chi^{2}$ test. Quantitative data were presented as means \pm SD analyzed using t-Student test. Multiple logistic regression with adjustment for confounding variables was applied for analysis of the association between LTF genotype and the risk of caries (DMFT $\geq 1$ ). Statistical significance was defined as $\mathrm{p}<0.05$. All data were analyzed using a data analysis software system (Dell Statistica, version 13. Dell Inc. 2016, software.dell.com).

\section{RESULTS}

The c.140A $>$ G $L T F$ transition (rs1126478 polymorphism) was identified by DNA sequencing (Fig. 1) in all 210 children consisting the studied group. There were 98 AA homozygotes (46.7\%), 95 AG heterozygotes (45.2\%) and 17 GG homozygotes $(8.1 \%)$ in the studied group and the LTF genotype distribution conformed to the expected Hardy-Weinberg equilibrium ( $p=0.362)$. The frequency of the LTF: c.140A major allele was $69.3 \%$. There were $168(80.0 \%)$ caries-affected children (DMFT $\geq 1)$ and $42(20.0 \%)$ caries-free children (DMFT $=0$ ) in the studied group, and the mean DMFT index was 3.1 \pm 2.6 . There were significant differences in the frequency distribution of LTF genotypes or LTF alleles between girls and boys. No significant differences in the caries prevalence and mean DMFT have been found between girls and boys. No significant differences in the distribution of gender, LTF genotypes or LTF alleles have been found between rural children and urban ones. The caries frequency and mean 
DMFT in rural children were significantly higher as compared with urban ones (Tab. 1). Multiple logistic regression with adjustment for gender and place of permanent residence in the whole studied group or for gender only in rural children and urban children analyzed separately revealed no significant association between LTF polymorphism and risk of caries (Tab. 2).

\section{DISCUSSION}

Lactotransferrin is a multifunctional immune protein that limits microbial growth through sequestration of essential iron [19]. Lactotransferrin also exhibits non-iron-dependent antibacterial, antifungal, antiviral, anti-inflammatory and immunoregulatory activities mediated by its highly charged $\mathrm{N}$ terminus, and these activities of lactotransferrin seem to be modulated by rs1126478 LTF functional polymorphism (c.140A $>\mathrm{G}$ transition), which results in $\mathrm{R}$ instead of $\mathrm{K}$ at amino acid position 47 (p.K47R) in the N-terminal region of the $L T F$ protein [14]. On the other hand, combined analyses of the data from the 1000 Genomes Project and the data from the Neanderthal genome browser strongly suggest an intriguing scenario for positive selection of the wild-type LTF: c.140A variant, including possible Neanderthal variant introgression into the modern human genome [19].

To the best of our knowledge, this study is a first report on LTF: c.140A>G (rs1126478) polymorphism in Poles. The frequency of the LTF: c.140A allele equal 69.3\% in 12-year-olds was close to frequencies from the 1000 Genomes Project in other European populations, which ranged $65.4-71.2 \%$. Only in Finns,
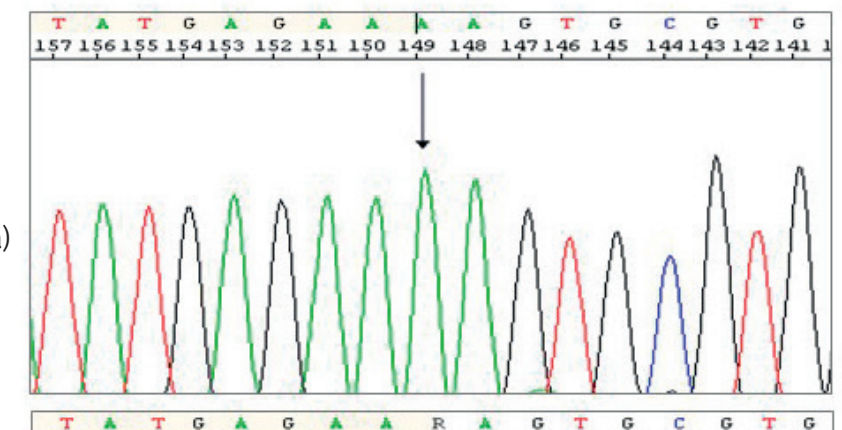

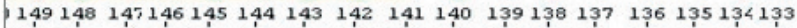

b)

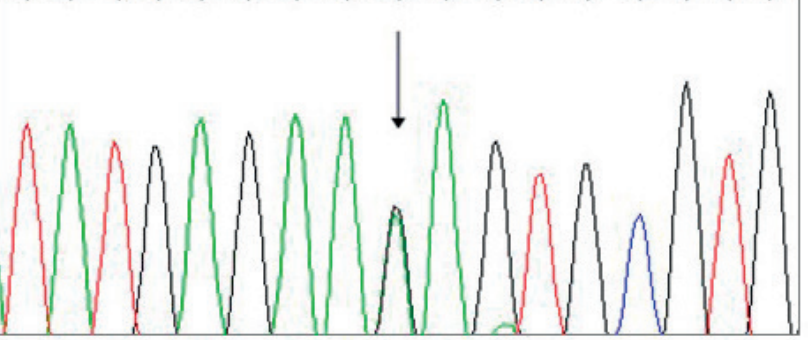

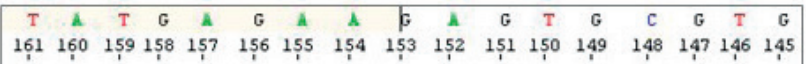

c)

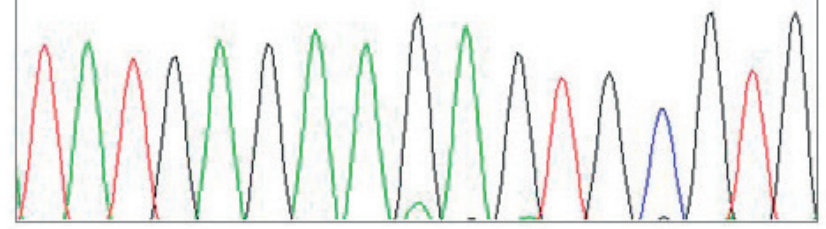

FIGURE 1. DNA sequence chromatograms of the c.140A>G (rs1126478) LTF polymorphism: a) AA homozygote; b) AG heterozygote; c) GG homozygote

TABLE 1. Clinical characteristics of the studied 12-year-old children in regard either to gender or to place of residence

\begin{tabular}{|c|c|c|c|c|c|c|}
\hline Variable & $\begin{array}{c}\text { Girls } \\
(n=107)\end{array}$ & $\begin{array}{c}\text { Boys } \\
(n=103)\end{array}$ & $p$ & $\begin{array}{l}\text { Rural children } \\
\qquad(n=59)\end{array}$ & $\begin{array}{l}\text { Urban children } \\
\qquad(n=151)\end{array}$ & $\mathrm{p}$ \\
\hline Gender F/M & - & - & - & $29 / 30$ & $78 / 73$ & 0.744 \\
\hline $\begin{array}{l}\text { LTF genotypes: } \\
\text { AA/AG/GG }\end{array}$ & $60 / 39 / 8$ & $38 / 56 / 9$ & 0.019 & $23 / 31 / 5$ & $75 / 64 / 12$ & 0.364 \\
\hline LTF alleles: A/G & $159 / 55$ & $132 / 74$ & 0.023 & $77 / 41$ & $214 / 88$ & 0.263 \\
\hline $\mathrm{DMFT}$ mean $\pm \mathrm{SD}$ & $3.3 \pm 2.7$ & $2.8 \pm 2.4$ & 0.220 & $4.3 \pm 2.7$ & $2.6 \pm 2.3$ & 0.00001 \\
\hline
\end{tabular}

DMFT - decay-missing-filled teeth

TABLE 2. Association analysis of rs1126478 LTF polymorphism and risk of caries in 12-year-old children from West Pomeranian region

\begin{tabular}{|c|c|c|c|c|c|c|c|c|c|c|c|}
\hline \multirow{2}{*}{ Group } & \multicolumn{2}{|c|}{ LTF (c.140A/c.140G) } & \multirow[t]{2}{*}{$\mathrm{p}$} & \multicolumn{3}{|c|}{ DMFT $\geq 1$} & \multicolumn{3}{|c|}{$\mathrm{DMFT}=0$} & \multirow[t]{2}{*}{ p } & \multirow{2}{*}{$\begin{array}{c}\text { OR } \\
(95 \% \mathrm{Cl}) \\
\end{array}$} \\
\hline & DMFT $\geq 1$ & $\mathrm{DMFT}=0$ & & AA & AG & GG & AA & AG & GG & & \\
\hline $\begin{array}{l}\text { Rural and } \\
\text { urban } \\
\text { children }\end{array}$ & $230 / 106$ & $61 / 23$ & 0.459 & 76 & 78 & 14 & 22 & 17 & 3 & $0.489^{a}$ & $\begin{array}{c}0.82 \\
(0.46-1.45)^{a}\end{array}$ \\
\hline $\begin{array}{l}\text { Rural } \\
\text { children }\end{array}$ & $70 / 40$ & $7 / 1$ & 0.171 & 20 & 30 & 5 & 3 & 1 & 0 & $0.164^{b}$ & $\begin{array}{c}0.21 \\
(0.02-2.01)^{b}\end{array}$ \\
\hline
\end{tabular}

p and OR ( $95 \% \mathrm{Cl}$ ) for additive mode of inheritance of the wild-type allele (LTF: C.14OA allele) in multiple logistic regression analysis with adjustment for gender and the place of permanent residence (a) or for gender only (b) 
a well-known example of a genetically-isolated population, was the frequency significantly lower (57.6\%) [20]. It is noteworthy that the frequency of the LTF: c.140A allele in Polish 12-yearold children was similar to a value $(74.9 \%)$ reported in Czech children who are also of Slavic origin [16].

Our results of significantly higher caries frequency and mean DMFT index in rural children as compared with urban subjects confirmed previous findings in Polish 12-year-old children [4, 5]. On the other hand, this study revealed no significant difference in the LTF rs1126478 genotype or allele distribution between caries-free subjects (DMFT $=0$ ) and subjects with caries (DMFT $\geq 1$ ) in the whole studied group as well as in rural children or in urban ones analyzed separately. Previously, a lack of association between LTF: c.140A $>$ G polymorphism and the susceptibility to caries (DMFT $\geq 1$ ) in children with permanent dentition has been reported in 12-year-old Brazilian subjects of European descent $(n=110)$ [8] and Czech children aged 11-13 years $(n=637)$ [16]. The only results of a study carried out in a small group of young adults revealed that LTF AA homozygotes were more likely to be caries-free than subjects with at least one G allele (AG or GG subjects) [15]. However, these results should be interpreted with caution due to small sample size $(\mathrm{n}=30)$ and inclusion of subjects with DMFT = 1 in the carriesfree group [15]. The lack of association between LTF: c.140A>G polymorphism and the susceptibility to caries in deciduous dentition (the susceptibility to severe caries defined as DMFT index $\geq 4$ ) has also been reported in children aged under 4 years ( $\mathrm{n}=1005)$ in China [17]. In addition, no significant association was previously found between LTF rs1126478 polymorphism and the severity of caries in Brazilian 12-year-old children (with comparison between children with DMFT $\leq 2$ and children with DMFT $\geq 3$ ) [8], in Czech children aged 11-13 years (comparison between children with DMFT $=1$, children with vs. $\leq 2$ DMFT $\leq 3$ and children with DMFT $\geq 4$ ) [16]. Due to no linkage disequilibrium between rs1126478 and other LTF polymorphisms (rs6441989, rs2073495, rs11716497, rs2269436, rs743658, rs4547741 and rs17078878) the studies of the latter provided no convincing evidence for association of LTF: c.140A $>$ G polymorphism with predisposition to caries [9, 21, 22].

\section{CONCLUSIONS}

Presented in the article study show a lack of association between LTF: c.140A $>$ G polymorphism and the risk of caries in Polish children with permanent dentition. In addition, our study confirms that residence in rural areas is an independent risk factor for caries in 12-year-old children. However, although our analysis involved a larger number of subjects than some similar analyses, the number of subjects was still relatively small and warrants further investigation using a larger sample size and application of statistical analysis of LTF genotypes with adjustment for clinical characteristics, socioeconomic factors, diet and oral behavioral habits.

\section{REFERENCES}

1. Kassebaum NJ, Bernabé E, Dahiya M, Bhandari B, Murray CJ, Marcenes W. Global burden of untreated caries: a systematic review and metaregression. J Dent Res 2015;94(5):650-8.

2. Rojek R, Stachowiak-Ruda J, Mikołajczyk J, Wieczkowska I, Jarząbek A, Gońda-Domin M, et al. Dental health practices verus oral health condition in 12-year-old children from West Pomerania Province. J Stoma 2017;70(3):272-80

3. Country Oral Health Profiles. Malmö University. https://www.mah.se/ CAPP/Country-Oral-Health-Profiles/ (5.06.2018).

4. Gaszyńska E, Wierzbicka M, Marczak M, Szatko F. Thirty years of evolution of oral health behaviours and dental caries in urban and rural areas in Poland. Ann Agric Environ Med 2014;21(3):557-61.

5. Rodakowska E, Wilczyńska-Borawska M, Bagińska J, Stokowska E. Epidemiological analysis of dental caries in 12-year-old children residing in urban and rural settings in the Podlaskie region of north-eastern Poland. Ann Agric Environ Med 2013;20(2):325-8.

6. Rojek R, Mikołajczyk J, Gońda-Domin M. Environment inhabited and condition of dental caries disease in 12-year-olds from the West Pomerania region, on the basis of epidemiological studies during the year 2011. Mag Stomatol 2014;24(11):121-4.

7. Navazesh M, Kumar SK. Measuring salivary flow: challenges and opportunities. J Am Dent Assoc 2008;139 Suppl:35S-40S.

8. Azevedo LF, Pecharki GD, Brancher JA, Cordeiro CA Jr, Medeiros KG, Antunes AA, et al. Analysis of the association between lactotransferrin $(L T F)$ gene polymorphism and dental caries. J Appl Oral Sci 2010;18(2):166-70.

9. Brancher JA, Pecharki GD, Doetzer AD, Medeiros KG, Cordeiro CA Jr, Sotomaior VS, et al. Analysis of polymorphisms in the lactotransferrin gene promoter and dental caries. Int J Dent 2011;2011:571726.

10. Van Nieuw Amerongen A, Bolscher JG, Veerman EC. Salivary proteins: protective and diagnostic value in cariology? Caries Res 2004;38(3):247-53.

11. Liu D, Wang X, Zhang Z, Teng CT. An intronic alternative promoter of the human lactoferrin gene is activated by Ets. Biochem Biophys Res Commun 2003;301(2):472-9.

12. Jenssen $H$, Hancock RE. Antimicrobial properties of lactoferrin. Biochimie 2009;91(1):19-29.

13. Kim SJ, Yu DY, Pak KW, Jeong S, Kim SW, Lee KK. Structure of the human lactoferrin gene and its chromosomal localization. Mol Cells 1998;8(6):663-8.

14. Velliyagounder K, Kaplan JB, Furgang D, Legarda D, Diamond G, Parkin $\mathrm{RE}$, et al. One of two human lactoferrin variants exhibits increased antibacterial and transcriptional activation activities and is associated with localized juvenile periodontitis. Infect Immun 2003;71(11):6141-7.

15. Fine DH, Toruner GA, Velliyagounder K, Sampathkumar V, Godboley D, Furgang D. A lactotransferrin single nucleotide polymorphism demonstrates biological activity that can reduce susceptibility to caries. Infect Immun 2013;81(5):1596-605.

16. Volckova M, Linhartova PB, Trefna T, Vlazny J, Musilova K, Kukletova M, et al. Lack of association between lactotransferrin polymorphism and dental caries. Caries Res 2014;48(1):39-44.

17. Wang M, Qin M, Xia B. The association of Enamelin, Lactoferrin, and Tumour necrosis factor alpha gene polymorphisms with high caries susceptibility in Chinese children under 4 years old. Arch Oral Biol 2017;80:75-81.

18. World Health Organization. Oral health surveys - basic methods. www. who.int/oral_health, 2013 (2018.06.05).

19. Barber MF, Kronenberg Z, Yandell M, Elde NC. Antimicrobial functions of lactoferrin promote genetic conflicts in ancient primates and modern humans. PLoS Genet 2016;12(5):e1006063.

20. National Center for Biotechnology Information. 1000 Genomes Browser. www.ncbi.nlm.nih.gov/variation/tools/1000genomes/?assm =GCF_000001405.25,201 (5.06.2018).

21. Abbasoğlu Z, Tanboğa I, Küchler EC, Deeley K, Weber M, Kaspar C, et al. Early childhood caries is associated with genetic variants in enamel formation and immune response genes. Caries Res 2015;49(1):70-7.

22. Doetzer AD, Brancher JA, Pecharki GD, Schlipf N, Werneck R, Mira MT, et al. Lactotransferrin gene polymorphism associated with caries experience. Caries Res 2015;49(4):370-7. 